\title{
Phenotypic study of egg production curve in commercial broiler breeders using Compartmental function
}

\author{
Abbas Safari-Aliqiarloo', Masoomeh Zare'1, Farhang Faghih-Mohammadi², Alireza Seidavi², \\ Vito Laudadio ${ }^{3}$, Maria Selvaggi ${ }^{3}$, Vincenzo Tufarelli ${ }^{3^{*}}$
}

\author{
${ }^{1}$ University of Guilan, Department of Animal Science, Rasht, Iran. \\ ${ }^{2}$ Rasht Branch, Islamic Azad University, Department of Animal Science, Rasht, Iran. \\ ${ }^{3}$ University of Bari 'Aldo Moro', Section of Veterinary Science and Animal Production, Department of DETO, Valenzano, Bari, Italy.
}

\begin{abstract}
The objective of this study was to analyze the effect of environmental factors on egg production curve traits in broiler breeders. The weekly egg production records of birds collected from four different flocks were used to estimate the egg production curve parameters using the Compartmental function $\left(\mathrm{y}=\mathrm{A}\left(1-\exp ^{-b(t-d)}\right) \exp ^{-c t}\right)$. The coefficient of determination $\left(\mathrm{R}^{2}\right)$ obtained by the model was 0.98 . Least squares analysis of variance indicated that the environmental factors such as hatchability and flock had significant effects on egg production curve traits. The highest correlation was observed between the weekly potential maximum yield and yield at the beginning of laying, whereas the lowest correlation was found between the weekly potential maximum production and production after peak yield. Associated factors with the increasing slope of egg production curves had a negative correlation with the decrease after peak. The correlation analysis showed that peak production had a negative and significant relationship with production towards peak and time to reach peak production, while there was a positive and significant correlation with the slope decrease after peak yield. The Compartmental function can be used as an alternative model to predict egg production traits in broiler breeders.
\end{abstract}

Key Words: equation, modeling, poultry

\section{Introduction}

The rate of egg production is the most important trait in layers because it determines the number of eggs produced in a given period. Many other factors, such as egg weight, shell integrity, and egg quality are also significant due to their contribution to the economic and market value of eggs produced. In this regard, one of the main concerns for poultry producers is how to best define egg production rate as a selection trait. The rate of egg production changes over time and can be represented in terms of a "production curve". The shape of the curve is defined by the following stages: sexual maturity (which marks the onset of production), followed by a stage of increasing production to a maximum; a peak production, followed by a steady decline of egg production; and persistency of production (Fialho and Ledur, 1997; Grossman and Koops, 2001;

Received: September 5, 2017

Accepted: November 14, 2017

*Corresponding author: vincenzo.tufarelli@uniba.it

Copyright (C) 2018 Sociedade Brasileira de Zootecnia. This is an Open Access article distributed under the terms of the Creative Commons Attribution License (http://creativecommons.org/licenses/by/4.0/), which permits unrestricted use, distribution, and reproduction in any medium, provided the original work is properly cited.
Gerben, 2006). Some factors influencing egg production are: body weight (Alvarez and Hocking, 2007; Selvaggi et al., 2015); environmental rearing conditions (i.e., temperature and humidity) (Heier and Jarp, 2001; Abad, 2003; Elijah and Adedapo, 2006), especially thermoneutral or comfort zone for birds (Lal et al., 2003; Peebles et al., 2006); bacterial and viral diseases (Spedding, 1988); and nutritional balance (Gavora et al., 1982; Flores, 1994; Hester, 2005; Rozenboim et al., 2007).

In modern layers, the production rate almost reaches its maximal biological potential (i.e., one egg/hen per day) during peak production; however, some variations exist among birds during this stage. Moreover, several environmental factors are well known to influence the hatchability, such as storage length and conditions, hen age, and egg quality (Gumulka et al., 2010); also, genetic factors influence directly or indirectly the egg production (Liptoi and Hidas, 2006; Yegani and Korver, 2008).

The use of mathematical models in animal production allowed researchers to describe and understand the biological processes and to evaluate the response variable effects. The purpose of modeling the egg production curve in poultry is to achieve a more detailed analysis of egg production cycle and to describe the curve phases and duration (Fialho and Ledur, 1997; Fialho et al., 2001). 
However, the efficiency and accuracy of the different available equations depend on the quality of information incorporated into the model (Bindya et al., 2010). In a recent review paper, Narinc et al. (2014) reported that the majority of the available works utilizing the Compartmental model are in pharmacokinetic studies aiming to estimate drug concentrations in compartments of living systems after administration by tablet or inoculum (McMillan, 1981). McMillan et al. (1970a,b) suggested the use of Compartmental model to describe egg production in Drosophila spp. Later, Timmermans (1975) indicated that the Compartmental model fitted well also for egg production data in poultry. Therefore, the objective of this study was to analyze environmental factors, such as hatchability and flock, influencing egg production curve parameters in commercial-type broiler breeders using the Compartmental function.

\section{Material and Methods}

This experiment was conducted in a poultry farm in Rasht, Iran (37 $\left.16^{\prime} 50^{\prime \prime} \mathrm{N}, 49^{\circ} 34^{\prime} 59^{\prime \prime} \mathrm{E}\right)$. The initial data set consisting of $6,773,396$ egg production records was obtained from a local commercial broiler breeder flock (Ross 308-Iran) during early egg production from 2013 to 2015. The number of eggs (egg/hen/day) was individually recorded with the onset of sexual maturity (week 24) until 64 weeks of age. The weekly number of eggs was calculated and used for analysis of egg production curve.

To describe the egg production curve and the associated production characteristics, the Compartmental function was applied in this study (McMillan et al., 1970a,b; McMillan, 1981; Mashaly et al., 2004).

The following function was used in this respect:

$$
Y_{t}=a\left(1-\exp ^{-b(t-d)}\right) \exp ^{-c t},
$$

in which $d$ is the yield at the beginning of egg laying, $a$ is the potential maximum weekly output of eggs, $b$ is the rate of increase in egg laying, and $c$ is the rate of decay of egg production.

The time required to reach peak yield $\left(\mathrm{T}_{\max }\right)$ was estimated as the ratio of $d+(1 / b) \ln [(b+c) / c]$ and the peak yield $\left(\mathrm{Y}_{\max }\right)$ using following formula:

$$
\mathrm{Y}_{\max }=\left[a b c^{(\mathrm{c} / \mathrm{b})}\right] / \mathrm{e}^{\mathrm{cd}}(\mathrm{b}+\mathrm{c})^{(1+(\mathrm{c} / \mathrm{b}))}
$$

This model is under the influence of two components. Initially, the rate of production is increasing rapidly according to the component $\mathrm{a}\left(1-\mathrm{e}^{-\mathrm{b}(1-\mathrm{d})}\right)$; this function increases asymptotically to $a$. Other factors cause the production to decline and correspond to the component of decrease $\mathrm{e}^{\mathrm{ct}}$ the dominant component after egg production has reached its maximum value.
The parameters of Compartmental function were estimated for individual hen by applying the non-linear Guess-Newton iteration method of SAS software (Statistical Analysis System, version 6.18). A fixed linear model was fitted on estimated egg production curve parameters and production characteristics to analyze the effects of environmental factors including flock and hatchability. Least squares analyses of variance were undertaken using of the GLM procedure of SAS.

The model was as follows:

$$
\mathrm{Y}_{\mathrm{ij}}=\mathrm{Hatch}_{\mathrm{i}}+\mathrm{Flo}_{\mathrm{j}}+\mathrm{Hatch}_{\mathrm{i}} \times \mathrm{Flo}_{\mathrm{j}}+\mathrm{e}_{\mathrm{ij}} \text {, }
$$

in which $Y_{\mathrm{ij}}$ is the dependent variable (egg production curve traits), Hatch ${ }_{i}$ is the effect of hatchability ( $\left.\mathrm{i}=1,2,3,4\right)$, $\mathrm{Flo}_{j}$ is the effect of flock $(\mathrm{j}=1,2,3,4), \mathrm{Hatch}_{\mathrm{i}} \times \mathrm{Flo}_{\mathrm{j}}$ is the interaction effects, and e is the random residual with an expected value of 0 and a variance of $\mathrm{e}^{2}$.

\section{Results and Discussion}

The coefficient of determination $\left(\mathrm{R}^{2}\right)$ was equal to 0.98, which indicated that Compartmental function has an good ability to evaluate egg production curve with high accuracy (Table 1). This is clearly illustrated also in the Figure 1, where the observed production data curve was compared with the predicted value curve estimated by the Compartmental model. The means of estimated parameters obtained fitting the individual egg production curves were not equal to the parameters obtained fitting the mean of these curves. This is because the models used to fit data were non-linear, and the curves were not synchronized. The Compartmental function has been used to describe the egg production for groups of hens that are synchronized for age at the first egg (Gavora et al., 1971; Cason and Britton, 1988; Thomas et al., 1994). The range of $\mathrm{R}^{2}$ values in the present investigation was in agreement with the findings of previous trials that adopted different models in layer-type

\begin{tabular}{|c|c|c|}
\hline Parameter $^{1}$ & Mean & Standard deviation \\
\hline $\mathrm{a}$ & 7.44 & 1.42 \\
\hline $\mathrm{b}$ & 0.047 & 0.04 \\
\hline $\mathrm{c}$ & 0.188 & 0.22 \\
\hline d & 0.802 & 0.005 \\
\hline $\mathrm{Y}_{\max } *$ & 5.12 & 0.98 \\
\hline $\mathrm{T}_{\max } * *$ & 33.0 & - \\
\hline $\mathrm{R}^{2}$ & 0.989 & - \\
\hline \multicolumn{3}{|c|}{$\begin{array}{l}\mathrm{T}_{\max } \text { - time required to reach peak yield; } \mathrm{Y}_{\max } \text { - peak yield; } \mathrm{R}^{2}-\text { coefficient of } \\
\text { determination. } \\
{ }^{1} \text { Modeled as: } \mathrm{y}_{\mathrm{t}}=\mathrm{a}\left(1-\exp ^{-\mathrm{b}(\mathrm{t}-\mathrm{d})}\right) \exp ^{-\mathrm{ct}} \text {, in which } \mathrm{y}_{\mathrm{t}} \text { is the egg production on } \\
\text { week } \mathrm{t} \text {, a is the potential maximum weekly output of eggs, } \mathrm{b} \text { and } \mathrm{c} \text { are factors } \\
\text { associated with the inclining and declining slope of the egg production curve, and } \mathrm{c} \text {. } \\
\text { is the parameter representing yield at the beginning of egg laying. } \\
* \text { Peak yield calculated as: }\left[\mathrm{abc} \mathrm{c}^{(\mathrm{c} / \mathrm{b})}\right] / \mathrm{e}^{\mathrm{cd}}(\mathrm{b}+\mathrm{c})^{(1+(\mathrm{c} / \mathrm{b}))} \text {. } \\
* * \text { Time required to reach peak yield calculated as: }(\mathrm{d}+(1 / \mathrm{b}) \ln [(\mathrm{b}+\mathrm{c}) / \mathrm{c}]) \text {. }\end{array}$} \\
\hline
\end{tabular}

Table 1 - Means and standard deviation of egg production curve parameters 
birds: Gavora et al. (1982) applied McMillan's model (97\%) and Cason and Britton (1988) applied the Compartmental model $(95.2 \%)$. The $\mathrm{R}^{2}$ values in the present study were also comparable with previous findings of Murthy (1998) for Linear and Reciprocal model (71.4-91.8\%) and Hyperbola (83.9-96.1\%) for egg production in laying-type chickens. Thomas et al. (1994) and Lal et al. (2003) identified the same models, viz., Rational Function and Quadratic Fit, to fit well to the flocks of laying-type chickens with similar $\mathrm{R}^{2}$ values as obtained in our study.

All analyzed traits were significantly affected by flock $(\mathrm{P}<0.01)$, and this was not unexpected since it is the outcome of differences in body weight of birds and age at sexual maturity (Table 2). The hatchability factor and bird age at the time of egg collection significantly influenced $d$ and $\mathrm{Y}_{\max }$ parameters, which are related to the time of start of egg production and yield at peak production. This last factor had no effects on the other parameters of egg production curve, which might be due to the limitation in egg collection interval. Poultry growth curve studies have shown that bird line and sex are important factors affecting the curve parameters (Mignon-Gasteau, 1999). In addition, Ahn et al. (1997) reported that using logistic function in turkeys, sex had a significant effect on growth curve parameters.

Hatchability had a significant effect on the traits evaluated in the current study, and this result is in agreement

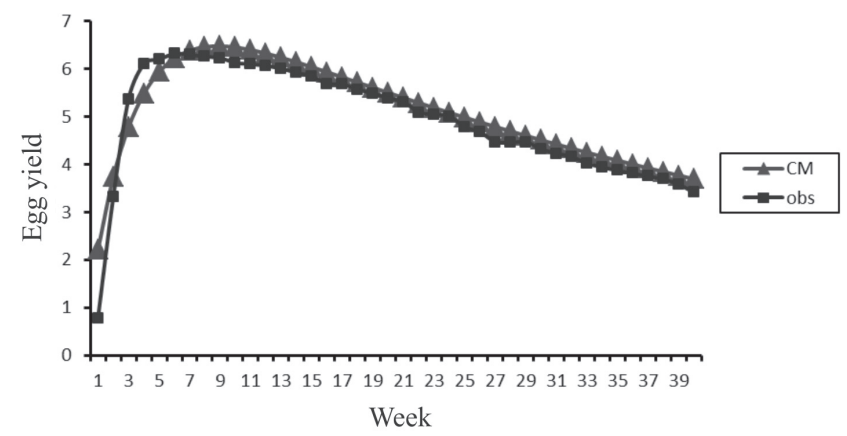

Obs - observed data; $\mathrm{CM}$ - estimated data

Figure 1 - Fitting of the Compartmental function to egg production curve. with previous findings obtained by Ahn et al. (1997). The interaction between hatchability and flock significantly affected $(\mathrm{P}<0.001)$ all evaluated traits, with the exception of $\mathrm{Y}_{\max }$ parameter, which is associated with peak production.

The first hatchability had the highest $\mathrm{T}_{\max }, b$, and $d$ parameters (Table 3 ). The lowest $\mathrm{T}_{\max }$ value was obtained at the fourth hatchability. The lowest $c$ value (the decrease after peak yield) occurred in the first hatchability. These results revealed that the lowest rate of production at initial egg laying occurred during the third hatchability. The parameter $b$, which is associated with production increase towards peak yield, did not change in relation to hatchability. The highest and the lowest peak yields were observed at the second and fourth hatchabilities, respectively. Nofal and Enany (2005) found that egg number and hen-day percentage were significantly decreased by advancing production interval after 40 weeks of age in Mamourah laying hens.

Results showed that parameter $a$, which is associated with the potential maximum weekly production, was negatively correlated with $c$ value, while it was positively correlated with $b, d$, and peak time (Table 4). The correlation analysis also revealed that the increased production towards peak yield had a positive correlation with the decrease after peak. Thus, birds that quickly reach peak production will rapidly decline egg production. Negative correlations were found between the parameters related to the production increase before peak and peak yield, indicating that birds with higher slope to peak production will have more egg production at peak. The parameter $c$, which is associated with the decrease after peak yield, had negative correlations with $a$ value, but it was positively correlated with the other evaluated parameters. Phenotypic correlation between the slope and time to reach peak production was significantly positive $(\mathrm{P}<0.001)$, indicating that birds reached the peak production more quickly. Therefore, the Compartmental function was successfully used to simulate population and production dynamics in analyzed data according to the present study.

Table 2 - Mean squares of variables from ANOVA for egg production curve traits

\begin{tabular}{|c|c|c|c|c|c|c|}
\hline \multirow{2}{*}{ Variable } & \multicolumn{4}{|c|}{ Egg production curve trait ${ }^{1}$} & \multirow{2}{*}{$\mathrm{T}_{\max }^{2}$} & \multirow{2}{*}{$Y_{\max }^{3}$} \\
\hline & $\mathrm{a}$ & $\mathrm{b}$ & $\mathrm{c}$ & $\mathrm{d}$ & & \\
\hline Flock (F) & $72.90 * *$ & $1.88 * *$ & $0.013^{* *}$ & $0.87 * *$ & $169.70^{* *}$ & $83.20 * *$ \\
\hline Hatchability (H) & $9.02 \mathrm{~ns}$ & $0.22 \mathrm{~ns}$ & $0.001 \mathrm{~ns}$ & $0.53 *$ & $18.29 \mathrm{~ns}$ & $13.43 * *$ \\
\hline $\mathrm{H} \times \mathrm{F}$ & $16.60^{*}$ & $0.23 \mathrm{~ns}$ & $0.002 * *$ & $0.25 * *$ & $24.75 * *$ & $4.33 * *$ \\
\hline Residual & 11.20 & 0.12 & 0.001 & 0.07 & 9.51 & 1.30 \\
\hline
\end{tabular}

ns - not significant.

${ }^{1}$ Modeled as: $\mathrm{y}_{\mathrm{a}}=\mathrm{a}\left(1-\exp ^{-\mathrm{b}(\mathrm{t}-\mathrm{d})}\right) \exp ^{-\mathrm{ct}}$, in which $\mathrm{y}_{\text {, is }}$ the egg production on week $\mathrm{t}$, $\mathrm{a}$ is the potential maximum weekly output of eggs, $\mathrm{b}$ and $\mathrm{c}$ are factors associated with the inclining and declining slope of the egg production curve, and $\mathrm{d}$ is the parameter representing yield at the beginning of egg laying.

${ }^{2}$ Time required to reach peak yield calculated as: $(d+(1 / b) \ln [(b+c) / c])$.

${ }^{3}$ Peak yield calculated as: $\left[\mathrm{abc} \mathrm{c}^{(\mathrm{c} / \mathrm{b})}\right] / \mathrm{e}^{\mathrm{cd}}(\mathrm{b}+\mathrm{c})^{(1+(\mathrm{c} / \mathrm{b}))}$.

$* \mathrm{P}<0.05$.

$* * \mathrm{P}<0.01$. 
Table 3 - Least square means for hatchability for egg production curve traits

\begin{tabular}{lcccccc}
\hline \multirow{2}{*}{ Variable } & \multicolumn{9}{c}{ Egg production curve trait ${ }^{1}$} & & \\
\cline { 2 - 5 } & $\mathrm{a}$ & $\mathrm{b}$ & $\mathrm{c}$ & $\mathrm{d}$ & & $\mathrm{Y}_{\max }{ }^{2}$ \\
\hline Hatchability & & & & & & \\
1 & $8.42 \mathrm{~b}$ & 0.41 & $0.03 \mathrm{~d}$ & $1.4 \mathrm{a}$ & $10.56 \mathrm{a}$ & $5.19 \mathrm{~b}$ \\
2 & $11.13 \mathrm{a}$ & 0.38 & $0.039 \mathrm{c}$ & $1.25 \mathrm{c}$ & $9.18 \mathrm{~b}$ & $5.39 \mathrm{a}$ \\
3 & $9.04 \mathrm{~b}$ & 0.36 & $0.046 \mathrm{~b}$ & $1.22 \mathrm{c}$ & $9.03 \mathrm{~b}$ & $4.57 \mathrm{c}$ \\
4 & $8.12 \mathrm{~b}$ & 0.39 & $0.051 \mathrm{a}$ & $1.30 \mathrm{~b}$ & $8.36 \mathrm{c}$ & $4.67 \mathrm{c}$ \\
\hline
\end{tabular}

${ }^{1}$ Modeled as: $\mathrm{y}_{\mathrm{t}}=\mathrm{a}\left(1-\exp ^{-\mathrm{b}(\mathrm{t}-\mathrm{d})}\right) \exp ^{-\mathrm{ct}}$, in which $\mathrm{y}_{\text {, is }}$ the egg production on week $\mathrm{t}$, $\mathrm{a}$ is the potential maximum weekly output of eggs, $\mathrm{b}$ and $\mathrm{c}$ are factors associated with the inclining and declining slope of the egg production curve, and $\mathrm{d}$ is the parameter representing yield at the beginning of egg laying.

${ }^{2}$ Time required to reach peak yield calculated as: $(\mathrm{d}+(1 / \mathrm{b}) \ln [(\mathrm{b}+\mathrm{c}) / \mathrm{c}])$.

${ }^{3}$ Peak yield calculated as: $\left[\mathrm{abc} \mathrm{c}^{(\mathrm{c} / \mathrm{b})}\right] / \mathrm{e}^{\mathrm{cd}}(\mathrm{b}+\mathrm{c})^{(1+(\mathrm{c} / \mathrm{b}))}$.

a-c - Means within each column with no common superscript differ significantly $(\mathrm{P}<0.05)$.

Table 4 - Pearson's correlation (phenotypic) coefficients for egg production curve traits

\begin{tabular}{|c|c|c|c|c|c|}
\hline \multirow{2}{*}{ Trait } & \multicolumn{3}{|c|}{ Egg production curve trait ${ }^{1}$} & \multirow{2}{*}{$\mathrm{T}_{\max }^{2}$} & \multirow{2}{*}{$\mathrm{Y}_{\max }{ }^{3}$} \\
\hline & $\mathrm{b}$ & $\mathrm{c}$ & $\mathrm{d}$ & & \\
\hline $\mathrm{a}$ & $0.06^{*}$ & $-0.8 \mathrm{~ns}$ & $0.87 * *$ & $0.319 *$ & $0.24 \mathrm{~ns}$ \\
\hline $\mathrm{b}$ & & $0.185 * *$ & $0.03 \mathrm{~ns}$ & $0.38 * *$ & $-0.36 * *$ \\
\hline $\mathrm{c}$ & & & $0.04 *$ & $0.51 *$ & $0.17 * *$ \\
\hline d & & & & $0.39 \mathrm{~ns}$ & $-0.19 \mathrm{~ns}$ \\
\hline $\mathrm{T}_{\max }$ & & & & & $-0.74 * *$ \\
\hline
\end{tabular}

ns - not significant.

${ }^{1}$ Modeled as: $\mathrm{y}_{1}=\mathrm{a}\left(1-\exp ^{-\mathrm{b}(\mathrm{t}-\mathrm{d})}\right) \exp ^{-\mathrm{ct}}$, in which $\mathrm{y}_{1}$ is the egg production on week $\mathrm{t}$, $\mathrm{a}$ is the potential maximum weekly output of eggs, $\mathrm{b}$ and $\mathrm{c}$ are factors associated with the inclining and declining slope of the egg production curve, and $d$ is the parameter representing yield at the beginning of egg laying.

2 Time required to reach peak yield calculated as: $(d+(1 / b) \ln [(b+c) / c])$.

${ }^{3}$ Peak yield calculated as: $\left[a b c c^{(c / b)}\right] / \mathrm{e}^{\mathrm{cd}}(\mathrm{b}+\mathrm{c})^{(1+(\mathrm{c} / \mathrm{b}))}$.

$* \mathrm{P}<0.05$.

$* * \mathrm{P}<0.01$

\section{Conclusions}

The Compartmental function can be used as an alternative model to predict egg production of broiler breeders.

\section{Acknowledgments}

Financial support by Rasht Branch, Islamic Azad University (grant number 4.5830) is gratefully acknowledged. This work was supported by Navid-Morgh Guilan Company, Rasht, Iran, for access to the data.

\section{References}

Abad, M. 2003. Reproducción e incubación en avicultura. Real Escuela de Avicultura, España.

Ahn, D. U.; Kim, S. K. and Shu, H. 1997. Effect of egg size and strain and age of hen on the solids content of chicken eggs. Poultry Science 76:914-919.

Álvarez, R. and Hocking, P. M. 2007. Stochastic model of egg production in broiler breeders. Poultry Science 86:1445-1452.
Bindya, L. A.; Murthy, H. N. N.; Jayashankar, M. R. and Govindaiah, M. G. 2010. Mathematical models for egg production in an Indian colored broiler dam line. International Journal of Poultry Science 9:916-919.

Cason, J. A. and Britton, W. M. 1988. Comparison of compartmental and Adams-BeU models of egg production. Poultry Science 67:213-218

Elijah, O. A. and Adedapo, A. 2006. The effect of climate on poultry productivity in Ilorin Kwara state, Nigeria. International Journal of Poultry Science 5:1061-1068.

Fialho, F. B. and Ledur, M. C. 1997. Segmented polynomial model for estimation of egg production curves in laying hens. British Poultry Science 38:66-73.

Fialho, F. B.; Ledur, M. C. and Avila, V. S. 2001. Mathematical model to compare egg production. Revista Brasileira de Ciência Avícola $3: 211-217$

Flores, A. 1994. Programas de alimentación en avicultura: ponedoras comerciales. p.103-105. In: Documentos FEDNA - X Curso de Especialización FEDNA, Madrid, España.

Gavora, J. S.; Parker, R. J. and McMillan, I. 1971. Mathematical model of egg production. Poultry Science 50:1306-1315.

Gavora, J. S.; Liljedahl, L. E.; McMillan, I. and Ahlen, K. 1982. Comparison of three mathematical models of egg production. British Poultry Science 23:339-348.

Gerber, N. 2006. Factors affecting egg quality in the commercial laying hen: A review. Egg Producers Federation of New Zealand Inc.

Grossman, M. and Koops, W. J. 2001. A model for individual egg production in chickens. Poultry Science 80:859-867.

Gumulka, M.; Kapkowska, E. and Maj, D. 2010 Laying pattern parameters in broiler breeder hens and intrasequence changes in egg composition. Czech Journal of Animal Science 55:428-435.

Heier, B. T. and Jarp, J. 2001. An epidemiological study of the hatchability in broiler breeder flocks. Poultry Science 80:11321138 .

Hester, P. Y. 2005. Impact of science and management on the welfare of egg laying strains of hens. Poultry Science 84:687-696.

Lal, K.; Singh, R. and Prasad, S. 2003. Non-linear models for poultry products in India. Indian Veterinary Journal 80:135-137.

Liptoi, K. and Hidas, A. 2006. Investigation of possible genetic background of early embryonic mortality in poultry. World's Poultry Science Journal 62:326-337.

Mashaly, M. M.; Hendricks, G. L.; Kalama, M. A.; Gehad, A. E.; Abbas, A. O. and Patterson, P. H. 2004. Effect of heat stress on production parameters and immune responses of commercial laying hens. Poultry Science 83:889-894.

McMillan, I. 1981. Compartmental model analysis of poultry egg production curves. Poultry Science 60:1549-1551.

McMillan, I.; Fitz-Earle, M. and Robson, D. S. 1970a. Quantitative genetics of fertility. I. Lifetime egg production of Drosophila melanogaster - Theoretical. Genetics 65:349-353.

McMillan, I.; Fitz-Earle, M.; Butler, L. and Robson, D. S. 1970 b. Quantitative genetics of fertility. II. Lifetime egg production of Drosophila melanogaster - Experimental. Genetics 65:355-369.

Mignon-Grasteau, S. 1999 Genetic parameters of growth curve parameters in male and female chickens. British Poultry Science 40:44-51.

Murthy, H. 1998. Genetic studies on components of egg production and trend of egg production curves in layer type birds. Ph.D. thesis. University of Agricultural Sciences, Bangalore, India.

Narinc, D.; Uckardes, F. and Aslan, E. 2014. Egg production curve analyses in poultry science. World's Poultry Science Journal $70: 817-828$ 
Nofal, M. E. and Enany, E. E. 2005. Effect of incorporating some copper compounds in the diet on productive, physiological and economical performance on the laying local chickens. p.657-667. In: Proceedings of the 2nd Conference of the Animal Production Research Institute, Sakha.

Peebles, E. D.; Basenko, E. Y.; Branton, S. L.; Whitmarsh, S. K.; Maurice, D. V. and Gerard, P. D. 2006. Effects of S6-strain Mycoplasma gallisepticum inoculation at ten, twenty-two, or forty-five weeks of age on the egg yolk composition of commercial egg-laying hens. Poultry Science 85:1502-1508.

Rozenboim, I.; Tako, E.; Gal-Garber, O.; Proudman, J. A. and Uni, Z. 2007. The effect of heat stress on ovarian function of laying hens. Poultry Science 86:1760-1765.

Selvaggi, M.; Laudadio, V.; Dario, C. and Tufarelli, V. 2015. Modelling growth curves in a nondescript Italian chicken breed:
An opportunity to improve genetic and feeding strategies. Journal of Poultry Science 52:288-294.

Spedding, C. R. W. 1988. An introduction to agricultural systems. 2nd ed. Elsevier Applied Science Publisher, London and New York.

Thomas, J. M.; George, K. C.; Raghunathan, N. and Nair, G. 1994. Prediction of egg production in Japanese quail. Indian Journal of Poultry Science 28:262-264.

Timmermans, M. P. F. C. A. 1975. Further investigation into the usefulness of a mathematical model to explain and predict egg production in poultry. p.121-148. In: Economic factors affecting egg production. Freeman, B. M. and Boorman, K. N., eds. Edinburgh, UK.

Yegani, M. and Korver, D. R. 2008. Factors affecting intestinal health in poultry: Review. Poultry Science 87:2052-2063. 